報 文

\title{
中国毛鳥素沙地で観察された旱柳の収穫環
}

\author{
新村義昭*
}

\section{The Harvest Cycle of Salix matsudana in Mao Wu Su Desert, China}

\author{
SHINMURA, Yoshiki*
}

\section{1. はじめに}

中国・内蒙古自治区の毛烏素沙地では, 砂の移動を止 めるための固砂林の造成に, 旱柳 (Salix matsudana) の 高杆挿し木造林が行われ, 良好な成績を上げている (小林ら，1989，吉川ら，1992）。また, この樹種は別名 空中草場と呼ばれ，沙地固定の働きの他に，羊を主とす る家畜の冬季間の飼料としての価值が高いことでも知ら れている2（徳岡ら，1989）。

このように乾燥地域において沙地固定の働きをしなが らなおかつ家畜の飼料ともなる旱柳が, 高杆挿し木造林 後, どのように取扱われているのかの技術体系を知るこ とは, これからの乾燥地緑化にとって非常に意義あるこ とだと考えた。なぜならば, 乾燥地においては緑化と同 時に飼料作物の生産が必要不可欠であるからである。

幸いにも，1991年夏にトヨ夕財団より研究助成を受け て実施されている，毛鳥素沙地開発研究中心との共同プ ロジェクトによる, 沙漠化の機構解明のための研究の一 環として現地に赴き, 高杆挿し木の材料としての挿し穂 がどのように生産され，その間にどのようにして飼料が 収穫されるのかの, いわゆる旱柳の収穫環の一部を調査 することができた。その結果, 興味深い技術体系の一端 を学ぶことができたので報告したい。

\section{2. 調査方法}

調査は研究中心およびその付近に生育する旱柳の林帯 または単木を対象として行った。

2.1 高杆插し木の間隔

高杆扦し木の間隔の測定は, 明らかに1991年の初春に

* 島根大学農学部附属演習林

Univ. For., Fac. of Agr., Shimane Univ.
挿し付けられたと認められた研究中心付近の林带（以下 当年生林帯) と, 研究中心開設直後の 1983 年ごろに, 北 西側から季節風の対策のために挿し付けられた研究中心 内の林帯 (以下西側林帯・写真 1 ) の 2 箇所で, 測量用 のテープを用いて行った。このとき, 当年生林帯では胸 高直径も同時に測定した。

\section{2 主軸数抢よび主軸跡の調査}

旱柳の先端部にすでに収穫されたと思われる主軸跡が 西側林帯で認められた。そこで, 主軸数と主軸跡数につ いて調査し, さらに主軸跡については直径測定後鋸断し て年輪数を数えた。また研究中心の付近に挿し付けられ た旱柳に対して, 単木的ではあったが, 主軸数と主軸跡 数を測定した。

ここで, 主軸とは多数の萌芽枝の中から将来的に高杆 挿し木の材料として収穫するために保存してある枝をい い, 主軸跡とはすでに過去に主軸であったもので, 収穫 のための伐採の痕跡を指すこととする。これらの関係を 模式的に表すと図 1 のようになる。

2.3 当年生萌芽枝の本数

研究中心付近に生育する旱柳の中から，1991年の春に

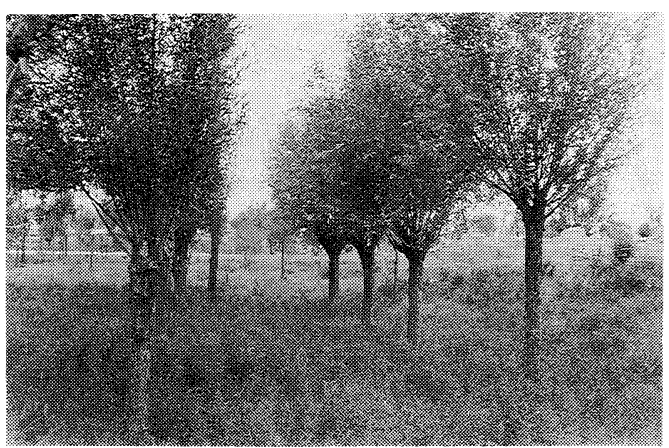

写真 1 研究中心構内の西側林帯 
主軸が収穫されその後に萌芽した当年生枝（シュート）

の数を単木的に選んで測定した。

\section{3. 結果と考察}

\section{1 挿し付け間隔と胸高直径}

表 1 は，1991年春に高杆挿し木造林された当年生の固 砂林帯の測定結果である。表から明らかなように, ここ での平均扦し付け間隔は約 $3 \mathrm{~m}$ と計算された。この值は 後述する西側林带の固砂林の間隔 (約 $3.5 \mathrm{~m}$ ) よりもやや 狭い。これはここでは統一された仕様書がないことによ るのかもしれない。

また同時に測定した胸高直径の平均值は $5.6 \mathrm{~cm}$ と計 算された。この值は小橋 ${ }^{1)}$ (1986) や小林ら ${ }^{3)}$ (1989) が 示した值 (平均 $3 \mathrm{~cm}$ ) よりもはるかに大きな值であった が, 徳岡ら ${ }^{2)}(1989)$ が示した太さ 4〜 $6 \mathrm{~cm}$ の範囲には収 まっている。

このことからすると,ここで取上げた林帯はごく平均 的な林帯であったと考えてよいだろう。

\section{2 主軸および主軸跡}

\section{1) 主軸数}

西側林帯が1983年の開設直後に造成されたとすれば, 1991年の時点で, すでに 9 年が経過したことになり, こ の間, ここの林帯では, 明らかに主軸の収穫が行われた 形跡が認められた。

そこで, この西側林带に 2 本の測線を設定し, 二代目 ともいうべき主軸数を測定した結果 (表 2 ), A 測線では $4 \sim 22$ 本の範囲内に, B 測線では10〜25本の範囲内にあ

表 1 旱柳の挿し付け間隔と胸高直径

\begin{tabular}{lrrrrrrrr}
\hline 個体番号 & 1 & 2 & 3 & 4 & 5 & 6 & 7 & 8 \\
\hline 距離 $(\mathrm{m})$ & 0 & 2.3 & 4.8 & 7.8 & 10.7 & 13.5 & 16.4 & 19.3 \\
直径 $(\mathrm{cm})$ & 4.8 & 5.6 & 7.6 & 5.8 & 5.6 & 5.8 & 4.5 & 4.1 \\
\hline 個体番号 & 9 & 10 & 11 & 12 & 13 & 14 & 15 \\
\hline 距離 $(\mathrm{m})$ & 21.8 & 24.8 & 28.0 & 30.9 & 33.7 & 36.7 & 39.8 \\
直径 $(\mathrm{cm})$ & 4.9 & 6.2 & 4.9 & 6.0 & 6.6 & 6.7 & 5.1 \\
\hline
\end{tabular}

つた。

2) 主軸跡数

主軸跡数は，B 測線でのみ調べた。その結果， 4 〜 15 本の範囲であった(表 2 )。この值は，前述した主軸数の 範囲内にあって, 主軸数の多少は, たとえば, 生育状況 の旺盛な個体にはより多くの主軸を生育させるなど，個 体の生育状況に応じて人為的に決められるものなのかも 知れない。

3）主軸跡直径

西側林帯で多数認められた主軸跡を無作為に選んでそ の直径を測定した。その結果主軸跡の直径は $5.0 〜 7.3 \mathrm{~cm}$ の範囲内にあった(表 2 )。この值は表 1 で示した胸高直 径の範囲内に収まっている。このことからすると, 高杆 挿し木の挿し穂として, かなり大きな主軸を収穫するこ とが示唆される。

実際研究中心付近の水溜まりに無造作に立て掛けられ ていた挿し穂を観察すると，ここで示した範囲内のもの が多かったように思われた。

4) 主軸跡年輪数

直径を測定したあと, 鋸断し年輪数を測定した(表 2 ・ 写真 2$) 。 そ の$ 結果， 6 例中 5 例の年輪数が 8 であった。 このことは,ここでは 8 年間生育させた後に収穫された

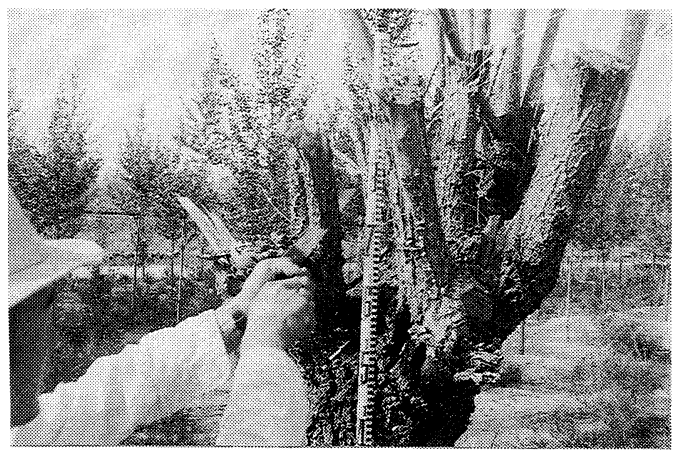

写真 2 旱柳の主軸跡の鋸断 上部に二代目の主軸が見られる

表 2 旱柳の主軸数・主軸跡数・主軸跡直径・主軸跡年歯

\begin{tabular}{|c|c|c|c|c|c|c|c|c|c|c|c|}
\hline \multirow{2}{*}{$\begin{array}{l}\text { 植栽列 } \\
\text { 個体番号 }\end{array}$} & \multicolumn{5}{|c|}{ A } & \multicolumn{6}{|c|}{ B } \\
\hline & 1 & 2 & 3 & 4 & 5 & 6 & 7 & 8 & $9-1$ & $9-2$ & 10 \\
\hline 挿し木距離 & 0 & 3.5 & 7.2 & 10.4 & - & 0 & 3.6 & 7.2 & 11.0 & & 14.4 \\
\hline 主軸数 & 11 & 4 & 22 & 8 & 15 & 10 & 17 & 25 & 14 & & 20 \\
\hline 主軸跡数 & & & & & & 4 & 10 & 12 & 14 & & 15 \\
\hline 主軸跡直径 & 5.7 & & & 6.5 & 7.3 & & & & 5.0 & 7.8 & 6.2 \\
\hline 主軸跡年齢 & 8 & & & 8 & 8 & & & & 6 & 8 & 8 \\
\hline
\end{tabular}


ことを意味している。ただ 1 例だけ年輪数が 6 であった のは, あとから，なんらかの事情で主軸として追加され たためだと思われる。

5) 萌芽数

主軸が収穫されると挿し付け直後の状態に近くなり, シュートが先端部に密生する(写真 3 )。1991年に主軸が 収穫されたと思われる旱柳を選んで，シュートの本数を 調查した(表 3 )。その結果，主軸数あるいは主軸跡数よ りも,明らかに多数のシュートを確認することができた。 このことは, 飼料としてのシュートの収穫時に，個体の 生育状況に応じて, 主軸とすべきシュートを選択するこ とが可能である事を示唆する。

6) 主軸数と主軸跡数

すでに主軸を収穫して, 主軸跡から萌芽したシュート を次世代の主軸として生育させている旱柳を抽出して主 軸数（次世代）と主軸跡数（前世代）のみを測定した（表 $4)$ 。その結果, 主軸数は 8〜20本の範囲にあって，これ までに示してきた值に近く，さらに，主軸跡数もまた 6 〜15本の範囲にあって同様の傾向を示した。

以上のことを収穫環の面から模式的にまとめてみると

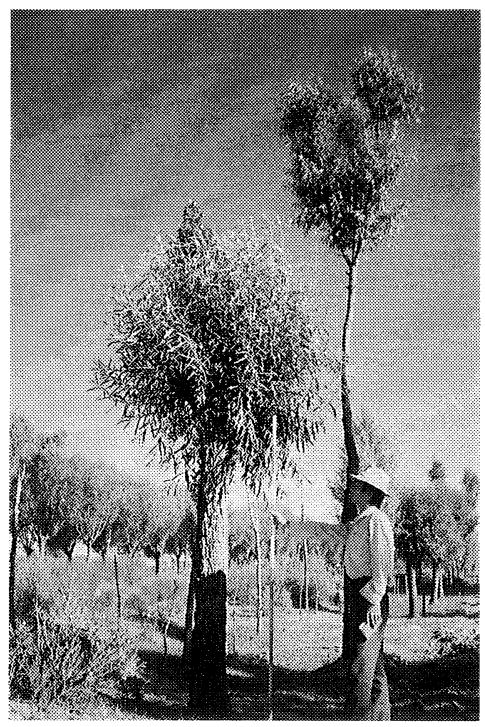

写真 3 主軸が収穫された後のシュートの旺盛な生育状 況

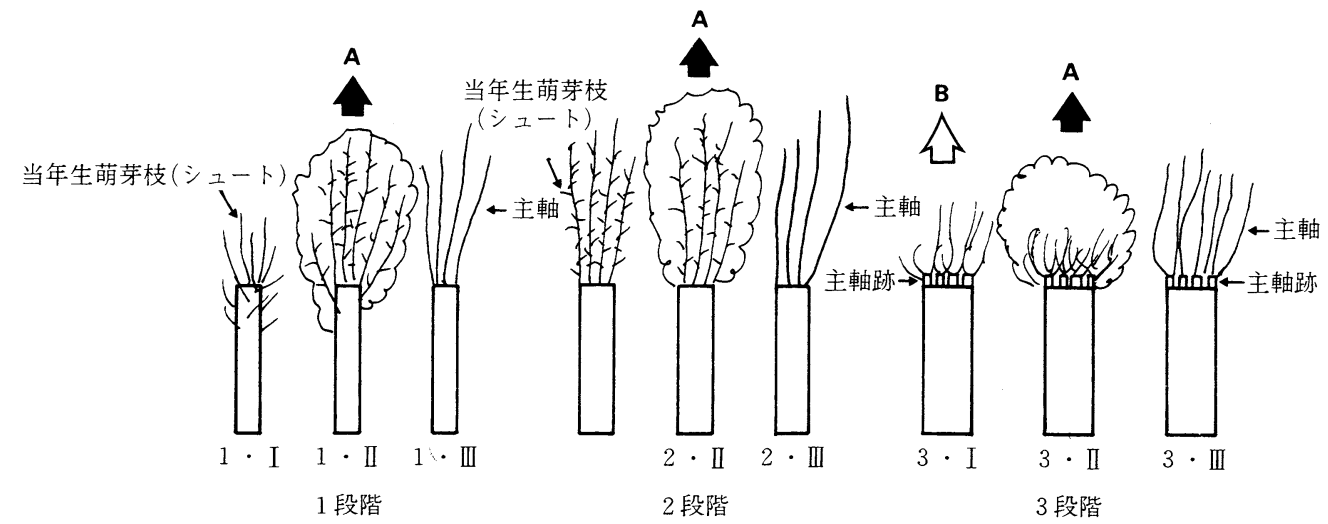

図 1 旱柳の利用部分と収穫環

$\mathbf{A}$ ：飼料として収穫

B：高杆挿し木の挿し穂として収穫

表 3 当年生萌芽枝 (シュート) 数

\begin{tabular}{|c|c|c|c|c|c|c|c|c|c|c|c|}
\hline 個体番号 & 1 & 2 & 3 & 4 & 5 & 6 & 7 & 8 & 9 & 10 & 11 \\
\hline 萌芽本数 & $50<$ & $50<$ & $50<$ & $50<$ & $50<$ & $50<$ & $50<$ & $50<$ & $50<$ & $50<$ & $50<$ \\
\hline
\end{tabular}

表 4 旱柳の主軸数と主軸跡数との関係

\begin{tabular}{ccccccccccccc}
\hline 個体番号 & 1 & 2 & 3 & 4 & 5 & 6 & 7 & 8 & 9 & 10 & 11 & 12 \\
\hline 主軸枝数 & 14 & 16 & 14 & 19 & 13 & 8 & 15 & 13 & 14 & 20 & 15 & 10 \\
主軸跡数 & 13 & 11 & 15 & 15 & 10 & 6 & 14 & 13 & 10 & 8 & 8 & 10 \\
\hline
\end{tabular}




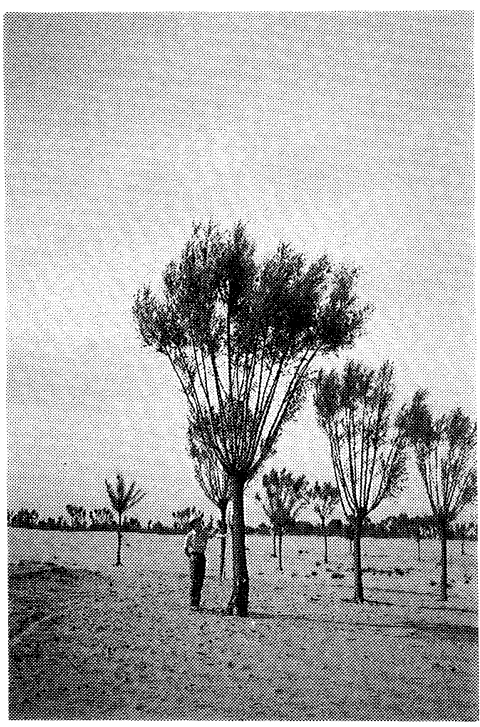

写真 4 生育の良い旱柳の主軸

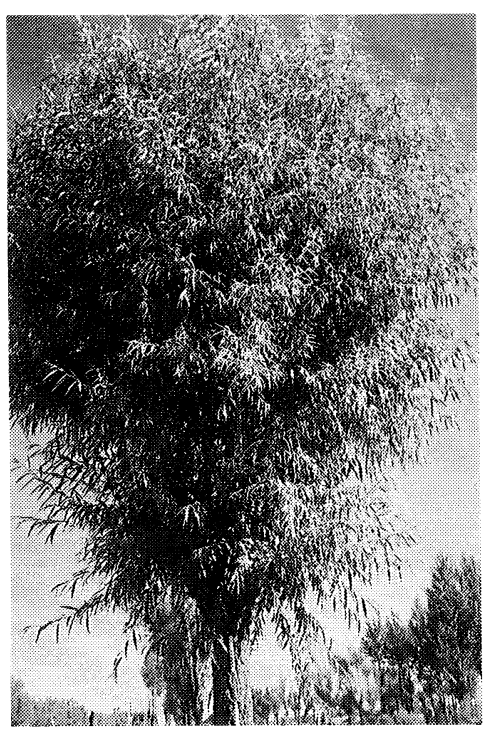

写真 52 世代のシュートの繁茂の状況（2・II段階）

网1のようになろう。すなわち，

1 段階：これは挿し付け当年である。この年はシュー トが多数（恐らく50本以上）発生し（1・I）, 旺盛に生 育する $(1 ・ I I)$ 。飼料の収穫時点で, 最も成長の良いシ ユートを, 旱柳の生育状態に応じて, 十数本主軸として 残し，他は飼料として，図中Aで表してあるように，全 て収穫する( $1 ・$ III )。

2 段階：翌年からは，主軸と挿し穂（台木）の両者か
らシュートが発生し（2・I），生育期間を通じて旺盛に 繁茂する（2・II，写真 5$)$ 。そして再び飼料の収穫時点 で, 主軸のみ残して他は飼料として, 図中Aで表してあ るように，全て収穫する（2・III）。この小さなサイクル は少なくとも 7 年間は繰返される。

3 段階：図中にBで表したように，春先に主軸が収穫 され（3・I ), 基本的には 1 段階と同じになると考えて よいが，ここでは主軸跡の有無で区別してみた。もちろ ん，主軸は明らかに商品として売買することができ，必 要なら現金収入の道を作り出すが，このことについては ここで深く触れないこととする。

さらに夏季に向かっていつもと同様に多数のシュート

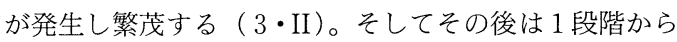
来たのと同じ経過をたどる。

以上がここでいう，旱柳の収穫環である。

筆者が北海道林試に在職中にナガバヤナギ類の埋幹の 施工過程を観察する機会があったが，そのときは，土中 に溝を掘り, 直径数 $\mathrm{cm}$ の幹を文字通り横に寝かせてそ の上から土をかぶせるという方法であった。

そこでは確かに発芽して旺盛な生育を示し, 裸地斜面 を被覆して，表面侵食を防ぐ効果を発揮した。しかしな がら，もしそこに放牧された家畜がいたとすれば，そし て牧柵がなかったとしたら，背丈が低い分，たちどころ に食べ尽されてしまったであろうと思われた。

その点ここで紹介した旱柳の高杆挿し木の方法は, 家 畜の被害にあうこともなく, 防風効果を発揮させながら なおかつ飼料を生産できる極めて合理的な技術であると いえよう。

乾燥地は一般に牧畜業が行われているのが普通であろ うから，これからもこのような有益な技術を学んで行き たいと考えている。

最後に，現地で調査を手伝って下さった葵 家声氏に 感謝いたします。

\section{参考文献}

1）小橋澄治：内蒙古自治区毛鳥素砂漠緑化利用の状況. 緑 化工技術，11(3)，15〜22，1986

2）徳岡正三・金 常元：中国内蒙古の毛烏素沙地開発整治 䂤究センター東試験地における植物目録. 京都府大演習 林報告 $33 ， 31 \sim 43 ， 1989$

3）小林達明・増田拓朗・小橋澄治：モウソ砂地に扔ける八 ンリュウの大枝じかざし造林の立地と生育の関係. 日本 緑化工学会誌15(2), 1 8, 1989

4）吉川 賢 - 小林達明 - 小橋澄治: 中国の半乾燥地带に生 育する樹木の葉の水分特性. 日本緑化工学会誌 17 ( 2 ), $1 \sim 9,1992$

(1992. 7. 20受理) 


\section{【新刊紹介】}

\section{中国沙漠植物志 全 3 巻}

中国科学院蘭州沙漠研究所編輯(劉媖心主編), 科学出 版社，北京，各巻それぞれ547，464，508ページ，1985， ' 87, '92年発行

中国北部には我国国土の約 4 倍のいわゆる砂漠や砂漠 化土地が広がっている。しかも, 毎年約 20 万 ha (東京都 とほほ同じくらいの広さ）の土地が砂漠化しているとい われる。しかし，一方では，1984年の UNEP (国連環境 計画）の報告にあるように，世界的にみて中国の砂漠や 砂漠化土地の改善はめざましい。事害，中国にはみごと によみがえった緑地をあちこちでみることができる。

1959年から本格的に砂漠の調査が始まり, その過程で 大量の植物標本が収集された。これが本書出版のきっか けになっている。最初の出版から全巻が揃うまで 7 年が 費やされたが, 乾燥地に成育している植物を大久的に収 録した図鑑は，中国はもとより，世界的にも例がないよ うに思える。

中国の砂漠，砂漠化土地はそれぞれ「沙漠」「沙地」 と表記され，…沙漠，…沙地と呼ばれる地域が, 遼寧,
内蒙古，陝西，寧夏，甘肃，新疆，青海の各省・自治区 内に 10 数箇所広がっている。本書では, これら沙漠, 沙 地に分布する植物をエングラー氏らの方式によって分類 している。各植物ごとに形態, 分布, 用途などが記述さ れ，第一巻ではマツ科からツヅラフジ科まで35科194属 605種，第二巻ではケシ科からセリ科まで 37 科 177 属 564 種, 第三巻ではサクラソウ科からキク科まで 24 科 184 属 525 種, 合計では実に 96 科 555 属1694種が収録されている。 このほか合わせて134の亜種, 変種, 品種が加えられてい る。乾燥地というきわめて劣悪な環境条件下でも, かく も多数の植物が成育していることに驚かされる。

それでも, 沙漠, 沙地に分布する植物がすべて収録さ れているわけではない。最も北東に広がる呼倫貝尔（フ ルンボイル) 沙地は未調査であり, 柴達木 (チャイダム) 盆地以外では, 海抜 $1500 \mathrm{~m}$ より高い地域の植物は収集 されていない。科尔沁 (カルチン) 沙地, 渾善達克 (フ ンシャンダーカー）沙地抢よび柴達木盆地の収集は不足 しているという。将来の続刊が期待される。

いずれにしても, 乾燥地緑化の基礎資料として,この 中国沙漠植物志全 3 巻が大いに貢献することであろう。

(徳岡正三) 